\title{
Analisis Pengaruh Waktu Aktivasi dan Adsorpsi dalam Pemanfaatan Karbon Aktif dari Serutan Kayu menjadi Adsorben Limbah Cair
}

\author{
Vibianti Dwi Pratiwi, Netty Kamal, Suparman Juhanda \\ Jurusan Teknik Kimia, Fakultas Teknologi Industri ITENAS, Bandung \\ Email: vibiantidwi@itenas.ac.id
}

\begin{abstract}
ABSTRAK
Industri pemanfaatan kayu cukup sering ditemukan di Indonesia, namun limbah yang dihasilkan tidak diolah dan hanya dibuang ke lingkungan. Limbah serutan kayu yang mengandung rantai karbon dapat dimanfaatkan menjadi karbon aktif. Pengaruh kualitas karbon aktif dari serutan kayu ini diuji berdasarkan waktu aktivasi dan daya adsorpsi limbah cair. Karbon aktif dibuat melalui pirolisis hingga mencapai suhu $500^{\circ} \mathrm{C}$ dengan ukuran 100-150 mesh dan diaktivasi dengan $\mathrm{H}_{3} \mathrm{PO}_{4} 10 \%$ selama 6 jam, 12 jam, dan 18 jam. Karbon aktif yang dihasilkan digunakan sebagai adsorben dan diujikan pada limbah cair zat warna tekstil Sumikaron Yellow Brown S-2RL. Adsorpsi dilakukan dengan variasi waktu 1 jam, 2 jam dan 3 jam. Selanjutnya larutan zat warna yang telah dijerap oleh karbon aktif dianalisa menggunakan spektrofotometer dengan panjang gelombang 480nm. Berdasarkan absorbansi atau konsentrasi (\%) pengurangan warna yang dihitung menggunakan anova dengan software Minitab 17, pengaruh yang lebih signifikan dalam pemanfaatan karbon aktif dari serutan kayu yaitu pada waktu aktivasi 12 jam dan waktu adsorpsi 3 jam. Karbon aktif dari limbah serutan kayu mampu mengurangi limbah cair zat warna sebesar 98,2519\%. Hasil uji pendahuluan dengan menghitung bilangan iod dari adsorben karbon aktif yang telah diaktivasi selama 12 jam menjadi kondisi terbaik dengan menjerap iod sebanyak 144,8961 mg/g.
\end{abstract}

Kata Kunci : limbah cair, karbon aktif, serutan kayu, Minitab

\begin{abstract}
The wood utilization industry is quite often found in Indonesia, but the waste produced is not processed and is only disposed of into the environment. Wood shavings containing carbon chains can be used as activated carbon. The effect of the quality of activated carbon from wood shavings was tested based on the activation time and adsorption liquid waste's capacity. Activated carbon is made through pyrolysis to reach a temperature of $500^{\circ} \mathrm{C}$ with a size of 100-150 mesh and activated with 10\% H3PO4 for 6 hours, 12 hours, and 18 hours. The activated carbon produced was used as an adsorbent and tested on the liquid waste of textile dye Sumikaron Yellow Brown S-2RL. Adsorption is carried out with variations of 1 hour, 2 hours and 3 hours. Furthermore, the dye solution that has been absorbed by activated carbon is analyzed using a spectrophotometer with a wavelength of 480nm. Based on the absorbance or concentration (\%) of color reduction calculated using anova with Minitab 17 software, a more significant effect on the utilization of activated carbon from wood shavings is the activation time of 12 hours and the adsorption time of 3 hours. Activated carbon from wood shavings waste is able to reduce dye wastewater by $98.2519 \%$. The results of the preliminary test by calculating iodine number from the adsorbent of activated carbon which has been activated for 12 hours are the best conditions by absorbing iodine is $144.8961 \mathrm{mg} / \mathrm{g}$.
\end{abstract}

Keywords : liquid waste, activated carbon, wood shavings, Minitab 


\section{PENDAHULUAN}

Jumlah industri menghasilkan berbagai macam produk guna memenuhi kebutuhan manusia pada saat ini semakin meningkat. Selain memberi dampak positif bagi pembangunan ekonomi, kegiatan industri juga memiliki dampak negatif. Kegiatan produksi akan menghasilkan limbah yang akan dibuang ke lingkungan. Limbah adalah sisa suatu hasil usaha atau kegiatan yang dibuang ke lingkungan dan sering kali dapat menurunkan kualitas lingkungan [1]. Salah satu limbah yang masih sering dibuang ke lingkungan adalah limbah serutan kayu.

Industri pemanfaatan kayu merupakan industri yang cukup banyak ditemukan di Indonesia. Namun limbah dari industri kayu berupa serutan kayu masih sering ditemukan di lingkungan sekitar. Salah satu kebijakan Departemen Kehutanan adalah memanfaatkan kayu seoptimal mungkin yang berarti bahwa semua industri pengolahan kayu berupaya untuk meminimalisir limbah kayu hasil produksi. Rendemen industri penggergajian kayu masih berkisar dari 50-60\%, sebanyak $15-20 \%$ terdiri dari serutan kayu gergajian. Diperkirakan jumlah serutan kayu gergajian di Indonesia sebanyak 0,78 ton $\mathrm{m}^{3} /$ tahun [2].

Limbah serutan kayu yang dihasilkan dapat merusak lingkungan bila tidak dimanfaatkan dengan baik. Pada industri besar, limbah serutan kayu gergajian dimanfaatkan sebagai briketarang dan dijual komersial. Namun untuk industri kecil yang jumlahnya ribuan unit dan tersebar di pedesaan, limbah serutan kayu masih belum dimanfaatkan secara optimal. Ditinjau dari komponen penyusunnya limbah serutan kayu dapat dimanfaatkan seperti bahan bakar dan arang aktif. Komponen primer dari kayu adalah selulosa (40-50\%), hemiselulosa (15-34\%) dan lignin (17-35\%) sedangkan sisanya adalah komponen sekunder dari kayu yang terdiri dari ekstraktif (1-10\%) dan abu $(<1 \%)$ [1], seperti yang ditunjukkan pada Tabel 1.

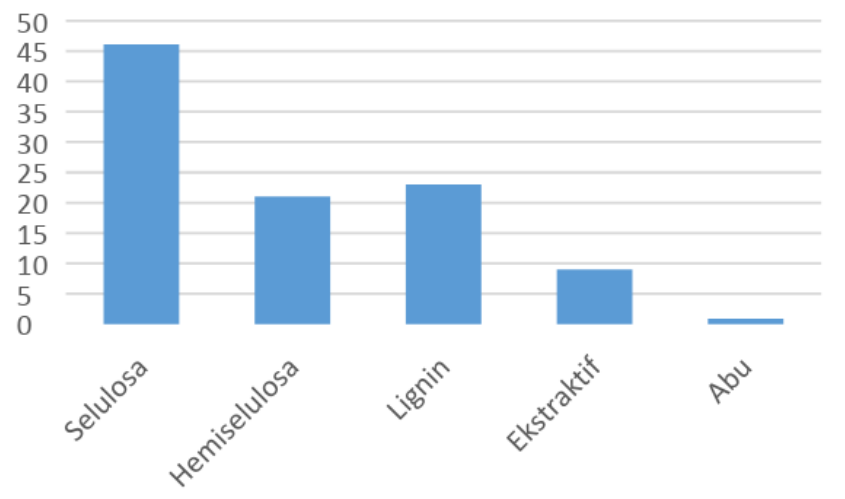

\section{Gambar 1. Prosentase Komponen Primer dan Sekunder pada Kayu}

Kandungan organik seperti rantai karbon panjang sangat berguna baik untuk bahan bakar maupun adsorben. Karbon aktif merupakan bahan adsorpsi dengan permukaan lapisan yang luas dengan bentuk butiran (granular) atau serbuk (powder). Dalam pengolahan air, karbon aktif digunakan sebagai adsorben untuk menghilangkan rasa, bau, dan warna yang disebabkan kandungan bahan organik dalam air. Senyawa yang mudah terjerap oleh karbon aktif umumnya memiliki nilai kelarutan dan ukuran poripori yang kecil dari karbon aktif [3].

Dasar pembuatan karbon aktif cukup berpengaruh dalam menentukan kualitasnya. Pembuatan karbon aktif berlangsung dengan 4 tahap yaitu dehidrasi untuk menghilangkan kandungan air, pirolisis mengubah kayu menjadi arang, karbonisasi membentuk karbon dari arang sehingga memiliki permukaan yang kecil dan spesifik, tahap terakhir aktivasi untuk menghilangkan hidrokarbon dari permukaan arang [3]. Pada penelitian ini menggunakan $\mathrm{H}_{3} \mathrm{PO}_{4} 10 \%$ untuk mengaktifkan arang menjadi karbon aktif dan pirolisis pada suhu $500^{\circ} \mathrm{C}$. 


\section{METODOLOGI PENELITIAN}

Metode percobaan yang digunakan dalam penelitian ini adalah eksperimental. Limbah serutan kayu dibuat menjadi karbon aktif yang akan menjerap limbah cair zat warna tekstil Sumikaron Yellow Brown S-2RL. Tahap pertama adalah dehidrasi menggunakan oven pada suhu $105^{\circ} \mathrm{C}$ selama 15 menit. Selanjutnya dipirolisis hingga mencapai suhu $500^{\circ} \mathrm{C}$ ke dalam reaktor fixed bed. Arang yang telah dipirolisis diayak hingga mendapatkan ukuran yang seragam yaitu 100-150 mesh kemudian diaktivasi secara kimia. Arang direndam dalam $\mathrm{H}_{3} \mathrm{PO}_{4} 10 \%$ selama 6 jam, 12 jam dan 18 jam sebagai variasi waktu aktivasi. Kemudian dikeringkan dalam oven pada suhu $180^{\circ} \mathrm{C}$ selama 2 jam.

Arang aktif atau karbon aktif yang telah siap dianalisa, diuji bilangan iod sebagai uji pendahuluan. Selanjutnya analisa kemampuan adsorben dari serutan kayu dengan memasukkan ke dalam wadah berisi limbah zat cair zat warna tekstil. Selain waktu aktivasi, variabel bebas pada penelitian ini adalah waktu adsorpsi karbon aktif terhadap zat warna. Variasi waktu adsorpsi adalah 1 jam, 2 jam, 3 jam dan 0 jam untuk blanko (pembanding). Setelah waktu adsorpsi selesai maka limbah cair zat warna diukur menggunakan spektrofotometer dan didapatkan \% pengurangan warnanya.

Pengukuran limbah zat cair menggunakan spektrofotometer pada puncak tertinggi dari panjang gelombang daerah sinar tampak. Selanjutnya hasil yang didapatkan dihitung menggunakan anova dengan software Minitab 17 untuk melihat perngaruh yang signfikan dari variabel bebas yang telah diteliti. Software Minitab 17 mengikuti persamaan dasar anova dngan tiga faktor pada eksperimen seperti pada persamaan berikut [4];

$$
\begin{gathered}
S S A=b \sum_{i=1}^{a}\left(\underline{y}_{i}-\underline{y}\right)^{2} \\
S S B=a \sum_{j=1}^{b}\left(\underline{y_{j}}-\underline{y}\right)^{2} \\
S S E=\sum_{i=1}^{a} \sum_{j=1}^{b}\left(y_{i j}-\underline{y_{i}}-\underline{y_{j}}+\underline{y}\right)^{2} \\
S S T=\sum_{i=1}^{a} \sum_{j=1}^{b}\left(y_{i j}-\underline{y}\right)^{2}
\end{gathered}
$$

Penelitian ini seluruhnya dilaksanakan di lingkungan kampus Itenas Bandung.

\section{HASIL DAN PEMBAHASAN}

Kayu adalah bagian batang atau cabang serta ranting tumbuhan yang mengeras karena mengalami lignifikasi (pengayuan). Kandungan organik terbesar pada kayu adalah selulosa dan lignin yang berguna sebagai pengikat bahan organik. Kayu sering digunakan untuk berbagai keperluan seperti perabotan rumah tangga, kantor bahkan bahan kertas [1]. Kebutuhan akan kayu meningkatkan industri besar maupun kecil untuk memproduksi kebutuhan manusia. Limbah kayu sisa produksi dari industri kayu akan menimbulkan kerusakan lingkungan. Limbah utama dari industri kayu adalah berupa potongan atau serpihan kayu hasil penggergajian serta debu dan serutan gergaji. Sebagian limbah kayu dimanfaatkan oleh masyarakat untuk bahan bakar industri kecil seperti batu bata, keramik atau dapur rumah tangga [5]. 
Pada penelitian Analisis Pengaruh Waktu Aktivasi dan Adsorpsi dalam Pemanfaatan Karbon Aktif dari Serutan Kayu menjadi Adsorben Limbah Cair bertujuan untuk meningkatkan nilai ekonomi dari limbah kayu. Limbah kayu yang mengandung karbon cukup tinggi dapat digunakan menjadi karbon aktif dengan melalui beberapa proses. Pada tahap pertama limbah kayu yang telah ditimbang dimasukkan ke dalam oven untuk proses dehidrasi pada suhu $105^{\circ} \mathrm{C}$ selama 15 menit. Pada proses dehidrasi ini, kadar air pada limbah serutan kayu akan berkurang bahkan menghilang. Tahap kedua adalah proses pirolisis untuk mendekomposisi secara kimia dan termal sehingga membentuk molekul yang lebih kecil. Pada proses pirolisis, rantai karbon yang panjang akan dipecah sehingga membentuk beberapa unsur karbon. Proses pirolisis dapat dilakukan pada beberapa suhu, waktu reaksi, tekanan, adanya gas dan keterlibatan katalis. Suhu yang umum digunakan dalam proses pirolisis hemiselulosa dan lignin sekitar $400-450^{\circ} \mathrm{C}$. Namun dengan kadar selulosa pada kayu yang terlampau tinggi maka digunakan proses flash pyrolisis pada suhu sekitar $400-600^{\circ} \mathrm{C}[6]$.

Arang atau karbon yang didapatkan dari hasil pirolisis digiling dan diayak hingga ukuran seragam sekitar 100-150 mesh. Tahap selanjutnya adalah proses aktivasi karbon atau arang dari serutan kayu. Proses aktivasi adalah suatu perubahan fisika dimana permukaan karbon aktif menjadi jauh lebih banyak karena hidrokarbon yang terkandung dalam karbon disingkirkan baik secara fisika maupun dengan cara kimia [3]. Pada umumnya secara kimia lebih mudah daripada fisika karena hanya membutuhkan bahan kimia sebagai activating agent. Aktivating agent yang digunakan pada penelitian ini adalah $\mathrm{H}_{3} \mathrm{PO}_{4} 10 \%$. Arang atau karbon yang telah dipirolisis direndam dengan $\mathrm{H}_{3} \mathrm{PO}_{4} 10 \%$ selama 6 jam, 12 jam dan 18 jam. Setelah direndam dengan beberapa variasi waktu aktivasi, arang atau karbon dari serutan kayu ini dikeringkan dengan oven pada suhu $180^{\circ} \mathrm{C}$ selama 2 jam.

Karbon aktif yang dihasilkan dari proses aktivasi digunakan sebagai adsorben dalam pengolahan limbah cair zat warna. Sebelumnya, karbon aktif yang dihasilkan perlu diuji daya adsorpsi terhadap bilangan iod pada uji pendahuluan. Bilangan iod dengan metode sentrifugal dan titrasi menggunakan natrium tiosulfat $0,1 \mathrm{~N}$ untuk setiap variasi waktu.

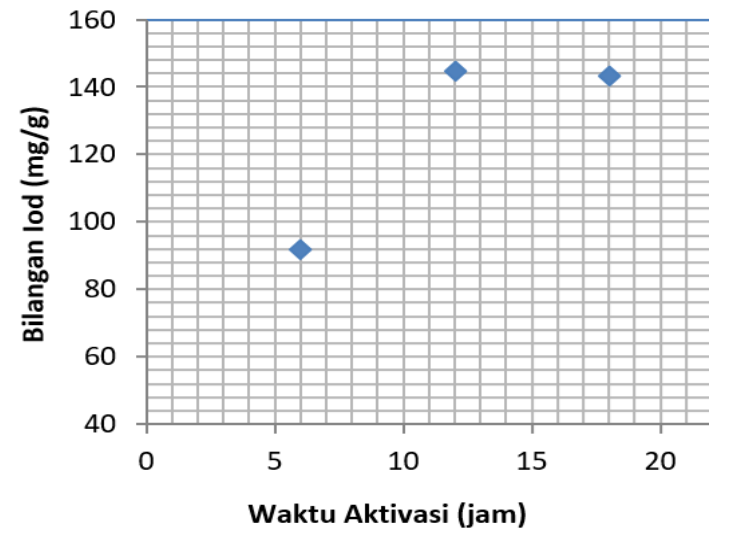

\section{Gambar 2. Kurva Bilangan Iod terhadap Waktu Aktivasi}

Berdasarkan kurva bilangan iod terhadap waktu aktivasi yang ditunjukkan pada Gambar 2, daya adsorpsi yang paling baik pada karbon aktif yang diaktivasi selama 12 jam. Pada karbon aktif dengan waktu aktivasi 12 jam mampu mengadsorpsi iod sebanyak 144,8961 mg/g. Daya adsorpsi karbon aktif terhadap iod memiliki korelasi dengan luas permukaan dari karbon aktif. Peningkatan bilangan iod terjadi sebagai akibat semakin banyak pengotor yang terlepas dari permukaan karbon aktif yang semula menutupi permukaan karbon aktif. Semakin besar luas permukaan karbon aktif maka semakin besar kemampuan adsorpsi karbon aktif tersebut [7]. Namun pada perolehan data penelitian, pada waktu aktivasi 18 jam, karbon aktif mulai jenuh sehingga penjerapan iodium tidak sesuai dengan teori. Oleh karena itu, daya adsorpsi terbaik pada penelitian ini adalah karbon aktif dengan waktu aktivasi 12 jam. 
Analisis Pengaruh Waktu Aktivasi dan Adsorpsi dalam Pemanfaatan Karbon Aktif dari Serutan Kayu menjadi Adsorben Limbah Cair zat warna tekstil Sumikaron Yellow Brown S-2RL dilakukan setelah adsorben diuji daya adsorpsinya. Larutan zat warna tekstil yang telah disiapkan diberi beberapa adsorben dengan variasi waktu aktivasi yang berbeda. Perendaman adsorben dalam zat warna tekstil selama 1 jam, 2 jam dan 3 jam. Selanjutnya diukur absorbansi pada spektrofotometer pada panjang gelombang $480 \mathrm{~nm}$ dan didapatkan \% pengurangan warna. Pengukuran absorbansi pada spektrofotometer setiap larutan zat warna dengan variasi waktu adsorpsi dan pada blanko zat warna yaitu saat 0 jam atau larutan zat warna tanpa penambahan adsorben. Hasil yang didapatkan dari pengukuran spektrofotometer ditunjukkan pada tabel 1 berikut;

Tabel 1. Pengaruh Waktu Aktivasi dan Adsorpsi terhadap Pengurangan Zat warna

\begin{tabular}{cccc}
\hline $\begin{array}{c}\text { Waktu } \\
\text { Aktivasi }\end{array}$ & $\begin{array}{c}\text { Waktu } \\
\text { Adsorpsi }\end{array}$ & Absorbansi & $\begin{array}{c}\text { \% Pengurangan } \\
\text { warna }\end{array}$ \\
\hline 0 jam & 0 jam & 2,517 & - \\
\hline \multirow{2}{*}{6 jam } & 1 jam & 2,167 & 13,9054 \\
\cline { 2 - 4 } & 2 jam & 1,411 & 43,9412 \\
\cline { 2 - 4 } & 3 jam & 0,130 & 94,5697 \\
\hline \multirow{2}{*}{12 jam } & 1 jam & 0,2625 & 87,5709 \\
& 2 jam & 0,094 & 96,2654 \\
\hline \multirow{2}{*}{18 jam } & 3 jam & 0,044 & 98,2519 \\
\cline { 2 - 4 } & 1 jam & 0,1285 & 94,8497 \\
\cline { 2 - 4 } & 2 jam & 0,136 & 94,5967 \\
\hline
\end{tabular}

Berdasarkan hasil yang ditunjukkan pada tabel 1, adsorben karbon aktif dari serutan kayu paling baik yang diaktivasi selama 12 jam dengan lama adsorpsi 3 jam. Nilai absorbansi berbanding lurus dengan konsentrasi zat warna yang terdapat dalam larutan. Hasil absorbansi paling rendah menunjukkan bahwa zat warna tekstil makin banyak terjerap oleh karbon aktif sehingga \% pengurangan warna menjadi besar. Oleh karena itu penurunan absorbansi menandakan adanya pengurangan konsentrasi zat warna di dalam limbah cair. Semakin lama waktu adsorpsi limbah zat cair warna, semakin kecil perolehan nilai absorbansinya [7].

Kemampuan karbon aktif dalam menjerap zat warna tekstil sebanding dengan uji pendahuluan. Karbon aktif yang diaktivasi selama 12 jam memiliki daya adsorpsi terbaik dibandingkan dengan kedua variasi waktu aktivasi lainnya. Begitu pula dengan proses adsorpsi zat warna tekstil yang paling besar daya adsorpsi pada waktu aktivasi 12 jam dengan waktu adsorpsi selama 3 jam. Pada waktu aktivasi 6 jam dan 18 jam, kemampuan adsorben dalam mengadsorpsi zat warna selama 1 jam, 2 jam dan 3 jam sesuai teori. Dimana semakin lama waktu adsorpsi, maka semakin banyak zat warna yang akan terjerap pada permukaan adsorben [7].

Analisis Pemanfaatan Karbon Aktif dari Serutan Kayu menjadi Adsorben Limbah Cair zat warna tekstil Sumikaron Yellow Brown S-2RL dihitung menggunakan anova dengan software Minitab 17 untuk melihat pengaruh yang signifikan antara waktu aktivasi dan waktu adsorpsi. Persentase pengurangan warna yang telah didapatkan dari penelitian diinputkan ke dalam software Minitab 17. Hasil perhitungan anova menggunakan software Minitab 17 dapat dilihat pada Tabel 2 berikut; 
Tabel 2. Perhitungan Anova dari \% Pengurangan Zat Warna Tekstil

\begin{tabular}{ccccc}
\hline $\begin{array}{c}\text { Source of } \\
\text { Varians }\end{array}$ & $\begin{array}{c}\text { Degree of } \\
\text { Freedom }\end{array}$ & Sum of Square & $\begin{array}{c}\text { Mean of } \\
\text { Square }\end{array}$ & F statistic \\
\hline Aktivasi & 2 & 3891,8 & 1945,9 & 4,10 \\
\hline Adsorpsi & 2 & 1496,5 & 748,2 & 1,58 \\
\hline Error & 4 & 1898,3 & 474,6 & \\
\hline Total & 8 & 7286,5 & & \\
\hline
\end{tabular}

F hitung ( $F$ statistic) pada Tabel 2 dibandingkan dengan $F$ tabel dengan derajat kepercayaan $75 \%$ yang bernilai 2,00. Jika F hitung lebih besar daripada $F$ tabel maka variabel bebas percobaan diterima dan ada pengaruh yang signifikan terhadap penelitian [8]. Hasil perhitungan anova menunjukkan waktu aktivasi karbon aktif lebih berpengaruh terhadap persentase pengurangan warna pada zat warna tekstil dibandingkan waktu adsorpsi. Hal tersebut juga ditunjukkan dari persamaan regresi dibawah ini;

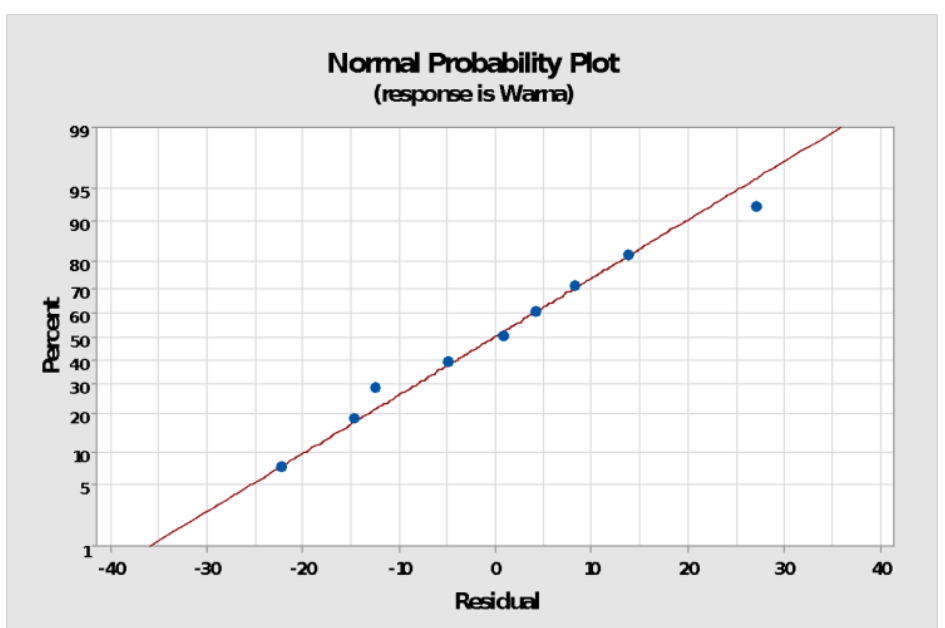

Gambar 2. Persamaan Garis Linear \% Pengurangan warna dengan Variasi Penelitian

$$
\mathrm{Y}=36,1+45,2 \text { Aktivasi_12 + 43,0 Aktivasi_18 + 12,8 Adsorpsi_2 + 31,4 Adsorpsi_3 }
$$

Pada persamaan regresi di atas memperjelas dari variabel yang signifikan atau mempengaruhi penelitian ini. Waktu aktivasi selama 12 jam yang lebih berpengaruh yang menunjukkan koefisien terbesar pada persamaan garis. Sedangkan waktu adsorpsi berpengaruh namun tidak sebesar pengaruh waktu aktivasi dengan waktu adsorpsi selama 3 jam paling berpengaruh dibandingkan dengan variasi yang lain. Hal ini ditunjukkan dengan persentase penghilangan warna tertinggi pada hasil penelitian yaitu 98,2519\% untuk adsorben yang diaktivasi selama 12 jam dengan proses adsorpsi 3 jam.

\section{KESIMPULAN}

Pada penelitian melihat Pengaruh Waktu Aktivasi dan Adsorpsi dalam Pemanfaatan Karbon Aktif dari Serutan Kayu menjadi Adsorben Limbah Cair zat warna tekstil Sumikaron Yellow Brown S-2RL yang dihitung menggunakan anova (analysis of variance) dengan software Minitab 17 didapatkan \% persentase pengurangan sebesar $98,2519 \%$. Persentase pengurangan warna terbesar terdapat pada adsorben yang diaktivasi selama 12 jam dengan proses adsorpsi 3 jam. Sehingga dapat disimpulkan bahwa \% pengurangan warna pada penelitian ini lebih dipengaruhi oleh waktu aktivasi daripada waktu adsorpsi. 


\section{DAFTAR PUSTAKA}

[1] Chandra, T. C., Mirna, M. M., Sunarso, J., Sudaryanto, Y., \& Ismadji, S. (2009, July). Activated Carbon from Durian Shell: Preparation and Characterization. Journal of the Taiwan Institute of Chemical Engineers, 40(4), 457-462.

[2] Hatmanto, B. P., \& Dwi, J. (2006). Ananlisis Teknologi Pengolahan Limbah Cair pada Industri Tekstil. Surakarta: PT. Iskandar Indah Printing Textile.

[3] Halim, Mirah, \& dkk. (2008). Pembuatan Karbon Aktif dari Pelepah Kelapa (Cocus Nucifera). Teknik KImia. Palembang: Universitas Sriwijaya.

[4] Walpole, R. E., Myers, R. H., Myers, S. L., \& Ye, K. (2012). Probability \& Statistics for Engineers \& Scientists nineth edition. Boston: Pearson Education, Inc.

[5] Andromeda, R. (2009). Makalah Limbah: Pemanfaatan Limbah Kayu untuk Pembuatan Briket Arang. Diambil kembali dari Academia.Edu:

http://www.academia.edu/6360138/Makalah_limbah

[6] Miranti, S. T. (2012). Pembuatan Karbon Aktif dari Bambu dengan Metode Aktivasi Terkontrol menggunakan Activating Agent H3PO4 dan $\mathrm{KOH}$. Teknik Kimia. Depok: Universitas Indonesia.

[7] Chandra, B. D., Muhara, I., Kamal, N., \& Juhanda, S. (2016). Pemanfaatan Karbon Aktif dari Serutan Kayu menjadi Adsorben dalam Pengolahan Limbah Cair. Teknik Kimia. Bandung: Institut Teknologi Nasional.

[8] Montgomery, D. C., \& Runger, G. C. (2003). Applied Statistic and Probability for Engineers Third Edition. New York: John Wiley \& Sons, Inc. 
Vibianti Dwi Pratiwi, Netty Kamal, Suparman Juhanda

Jurnal Rekayasa Hijau - 78 